Preference is given to letters commenting on contributions published recently in the JRSM. They should not exceed 300 words and should be typed double spaced

\section{Curtailment of higher surgical training in the UK}

Examining the potential impact of the proposed two-year cut in otology training, Jaydip Ray and colleagues conclude that intensification of training would be necessary to eradicate the significant difference in specialist surgical experience between current year-four and year-six otology trainees (June $2005 \mathrm{JRSM}^{1}$ ). In our opinion their article misses the point regarding the changes. The proposed model of four years' general training followed by two years of specialist training will not require future year-four trainees to have comparable operative experience to today's year-six trainees, as implied. The Specialist Advisory Committee for Otolaryngology has set stage-specific criteria of required operative competencies for higher surgical trainees. ${ }^{2}$ Georgalas et al., ${ }^{3}$ in a recent survey of otolaryngology trainees, concluded that all stage-specific criteria were currently being met, and that training standards were satisfactory across the UK. They concluded that current training is adequate and that a system of twotier trainees, with four years of general training and two years devoted to the subspecialties, would be an adequate option for the vast majority of specialist registrars, provided that current standards are maintained. ${ }^{2}$ Training in specialist otological surgery will not be offered or assessed in the new four-year 'generalist' higher surgical rotations, since specialist experience will be gained in accredited otology fellowships for prospective otologists.

\section{Dominic Bray}

\section{Codruta Neumann}

\section{Meredydd Harries}

Department of Otolaryngology, Royal Sussex County Hospital, Brighton, UK E-mail: dbray@doctors.org.uk

\section{REFERENCES}

1 Ray J, Hadjihannas E, Irving RM. Curtailment of higher surgical training in the UK: likely effects on otology. $J R$ Soc Med 2005;98:259-61

2 Joint Committee for Higher Specialist Training [http://www.jchst.org/ pdf/oto_curric.pdf]

3 Georgalas C, Hadjihannas E, Ghufoor K, Pracy P, Papesch M. Operative training in otolaryngology in the United Kingdom: a specialist registrar survey. J Laryngol Otol 2005;119:356-61

\section{Local anaesthesia for venepuncture}

I share the opinion of Dr Yentis (April $2005 \mathrm{JRSM}^{1}$ ) on local anaesthesia for venous cannulation. A venerable consultant teacher of mine, when criticized for using local before siting any intravenous device 'because the local hurts anyway', used to respond with the following offer: 'I will put up a drip on myself using my technique' (flourishing a $2 \mathrm{~mL}$ syringe with $0.5 \mathrm{~mL}$ lidocaine and a $27 \mathrm{G}$ needle), 'if you will put up a drip on yourself using your technique' (flourishing a $14 \mathrm{G}$ cannula complete with its needle/ introducer). He assured me nobody had ever taken him up on his offer.

\section{J Bowley}

Department of Anaesthetics, Nottingham City Hospital, Nottingham NG5 1PB, UK E-mail: john@jbowley.my-bulldog.com

\section{REFERENCE}

1 Yentis S. Taking the sting out of needles. J R Soc Med 2005;98:178-9

\section{Taking an 'ethics history'}

In 2001 my colleagues and I published an article in the Journal of Medical Ethics entitled 'The value of taking an "ethics history". '1 In this article we coined the term an 'ethics history', to describe a series of questions that could be used as an addendum to medical history taking in a clinical context. These questions were:

1. Do you know much about your illness?

2. Would you like further information?

3. If a member of your family approached us to find out what was wrong with you would you like us to tell them?

4. Do you think we should ask you first?

5. If something serious was wrong with you, would you want us to tell you (or someone else) or would you prefer not to know?

6. If you needed risky treatment would you want to decide for yourself? If not who should decide?

7. Very occasionally patients have what is called a cardiac arrest ... Usually doctors decide what to do, but some patients prefer to decide for themselves. Would you like to make this decision? Would you like us or a family member to decide?

8. Some people have advance directives or living wills. Have you heard of this?

9. If so are there any such directives that you would want us to know about?

We took this history from 56 competent patients, and showed that taking an 'ethics history' is a simple and not particularly time-consuming way of obtaining useful information about patients' preferences. That was why we did not need to question its value in the title.

The June JRSM included an article by Das and Mulley entitled 'The value of an ethics history?' ${ }^{2}$ in which these authors suggest that an 'ethics history' could be taken in an outpatient setting. They propose/offer seven key questions 
which incorporate (with minor modification) all of the questions from our original article, yet no acknowledgment of the source is given. They also fail to acknowledge the source of their idea - an 'ethics history' — although the title of their article is virtually peeled off ours.

I would appreciate an explanation for these irregularities.

\section{Gwen M Sayers}

Imperial College School of Medicine, London, UK

\section{REFERENCES}

1 Sayers GM, Barratt D, Gothard C, Onnie C, Perera S, Schulman D. The value of taking an 'ethics history'. J Med Ethics 2001;27:114-17

2 Das AK, Mulley GP. The value of an ethics history? J R Soc Med 2005;98:262-6

\section{Authors' reply}

Our review was inspired in large measure by the original work of Dr Sayers and her colleagues, to which we did refer. Somehow, in the course of repeated redrafting, we lost the passage that made clear our aim - to echo their recommendations and offer further points for consideration. We apologize unreservedly for this error.

\section{A K Das}

\section{G P Mulley}

Elderly Services Directorate

St James's University Hospital, Leeds LS9 7TF, UK

\section{Bubonic plague in the Book of Samuel}

In 2000 the pages of the JRSM saw an intriguing exchange concerning an illness described in the Hebrew Bible. The story in 1 Samuel is that the Philistines, having captured the Ark of the Lord from the Israelites, experienced an outbreak of 'tumours' (Hebrew ophal), and the affliction followed them as they moved the Ark from city to city. Concluding that the Ark was responsible for this disaster, the leaders decided to return it to the Israelites along with a guilt offering of five golden tumours and five golden rodents (akbar). But soon after the arrival of these 'statues' (probably small wooden models covered with gold) in Beth-shemesh seventy Israelites died in that city. Evaluating this epidemic, JP Griffin ${ }^{1}$ concluded that the outbreak was plague, with its associated buboes. But WMS Russell ${ }^{2}$ responded that Griffin was 'certainly erroneous' because of a mistranslation (the tumours being haemorrhoids due to dysentery) and because the rat carrier of plague was not in advances in archaeology have shifted the weight of evidence towards Griffin; moreover, the 'emerods' of the King James Bible appear in all modern translations as tumours.

Bubonic plague, caused by Yersinia pestis, is transmitted by the bite of the flea Xenopsylla cheopsis. This flea lives off the blood of many species besides man but its most notorious relationship is with the black rat (Rattus rattus). Recent archaeological evidence has caused a rethinking of plague in the ancient Near East. Fossilized remains of the plague flea have been found in large numbers in Amarna, Egypt $^{3}$ and, since Amarna was occupied for only a few years, we can date this contact between human beings and plague fleas accurately to about $1350 \mathrm{BC}$ - which is before the events described in the Book of Samuel. Moreover, archaeological studies in the Nile Valley indicate that $R$. rattus was introduced at this time, probably via ships from India. Evidence of bubonic plague has not been seen in Egyptian mummies but all the vectors were in place. ${ }^{4}$ These vectors could have spread a few miles north to Philistia.

From the story, it seems that the most characteristic features of the epidemic were rats and tumours. Dead rats, killed by the same bacillus that kills human beings, are seen in the streets of plague towns; and enlarged lymph nodes in the groin and axillae are the most obvious features of the illness. Why did the Philistines send statues of rodents and tumours to their neighbours? One interpretation is that the Philistines were offering a friendly warning: 'We have experienced an epidemic and these are the things you should look out for'. Another is that the statues represented the essence of the judgment that had descended upon the Philistines, who hoped that the affliction would be passed on.

The above analysis assumes that the story of the epidemic, as told in 1 Samuel, is based on an actual occurrence. A widespread view is that biblical stories of this sort are the product of a religious reform movement that flourished hundreds of years after Samuel, in the late Iron Age; but it is acknowledged, nonetheless, that they may have historical kernels. ${ }^{5}$ The kernel here is large enough to indicate that, even if the account is fictitious, it is based on a personal knowledge of plague.

\section{Frank R Freemon}

Vanderbilt University, Nashville, Tennessee, USA

Correspondence to: 2422 Valley Brook Road, Nashville, TN 37215, USA

\section{REFERENCES}

1 Griffin JP. Bubonic plague in biblical times. J R Soc Med 2000;93:449

2 Russell WMS. Plague, rats and the Bible. J R Soc Med 2000;93:553

3 Panagiotakopulu E. Fleas from Pharaonic Egypt. Antiquity 2001;75:499 55

4 Panagiotakopulu E. Pharaonic Egypt and the origin of plague. J Biogeogr 2004;31:269-76

5 Finkelstein I, Silberman NA. The Bible Unearthed: Archaeology's New Vision of Ancient Israel and the Origin of its Sacred Text. New York: Free Press, 2001:23 


\section{Disclosure of medical error}

Professor Kalra and his colleagues (July $2005 J R S M^{1}$ ) provide a useful overview of disclosure policies in different jurisdictions, but in other respects their account is less than robust. With reference to the UK, they state that the 'duty of candour' was 'declared' by the National Health Service in 2003. In fact it appears as Recommendation 12 in the Department of Health publication Making Amends, ${ }^{2}$ to which Kalra et al. surprisingly do not refer, although they do cite a reference to a relevant news item. ${ }^{3}$ A professional duty of candour already exists, and is currently expressed in the General Medical Council's guidance Good Medical Practice. ${ }^{4}$ Legally speaking, Making Amends acknowledges use of the phrase 'duty of candour' in a judgment of Sir John Donaldson, Master of the Rolls, in 1987. ${ }^{5}$ Kalra et al. refer to 'this scheme', without stating which scheme. Presumably they are referring to the NHS Redress Scheme, contained in other proposals of Making Amends, some of which, rather than being declared, are due to be considered by the UK Parliament in the current session. ${ }^{6}$

I was very surprised by the concluding comment, 'suits filed solely for monetary considerations abuse the tort system and set an unacceptable trend,' the cited authority for which is a letter published in another journal by the same authors, ${ }^{7}$ which does not, in my view, substantiate their latest assertions. The tort system is criticized, with good reason, but often it can only offer monetary compensation to claimants whose injuries cannot be reversed. The suggestion that claimants injured through medical fault are abusing the system by making claims needs reliable justification.

\section{Peter Gooderham}

Cardiff Law School, Museum Avenue, Cardiff CF10 3XJ, UK

E-mail: GooderhamEP@Cardiff.ac.uk

\section{REFERENCES}

1 Kalra J, Massey KL, Mulla A. Disclosure of medical error: policies and practice. J R Soc Med 2005;98:307-9

2 Department of Health. Making Amends. London: DoH, 2003

3 Dyer C. NHS staff should inform patients of negligent acts. BMJ 2003;327:7

4 General Medical Council. Good Medical Practice. London: GMC, 2001

5 Naylor $v$ Preston Area Health Authority (1987) 2 All ER 353

6 Queen's Speech. Hansard, House of Lords, 17 May 2005 [www.parliament.uk]

7 Kalra J, Massey KL, Mulla A. Disclosure of errors. Health Affairs $2004 ; 23: 273-4$

\section{Author's reply}

Although a professional 'duty of candour' was in place even before its introduction by the National Health Service (NHS) in 2003, it was only then that it was mandated as part of sweeping reforms in the clinical negligence system.
The duty of candour was a recommendation in the Department of Health publication Making Amends but was formalized in the form of a redressal scheme through the NHS. Our article intended to address the current practices and initiatives in honest disclosure of errors, a component of good medical practice, and not the historical aspects of the issue. Also, it appears that Dr Gooderham has misinterpreted our remarks about the current tort system. Our assertion with respect to the 'suits filed solely for monetary considerations' was directed towards the dishonest claimants/claims, which we consider as abuse of the tort system. It was by no means intended to question the right to compensation when claims are genuine.

\section{Jawahar Kalra}

Department of Pathology, College of Medicine,

Royal University Hospital, Saskatoon, SK, S7N 0W8, Canada

\section{Quartet of Unlikely Discoveries}

In his review of Quartet of Unlikely Discoveries R I S Bayliss concludes that the Taits' achievements might have been more widely acknowledged 'If only aldosterone had proved more significant in human physiology and had a more important role in human ill-health.... In fact, aldosterone antagonists have lately entered a new era with the recognition that aldosterone has adverse effects on the heart and is involved in inflammation of the vasculature. Several clinical trials, which are referenced in the text of the book, have shown aldosterone antagonists both new and old to be remarkably effective. Moreover, studies from several centres have shown a substantial prevalence of primary aldosteronism among patients with 'esssential hypertension': the diagnostic assays are critical, but rates of $5 \%$ to $15 \%$ have been cited depending upon the patient watershed and other factors. All this is encapsulated in a recent scholarly review, 'The new biology of aldosterone', by J M Connell and Eleanor Davies, J Endocrinol 2005;186:1-20. There are factual errors in Bayliss's book review. The Taits did not contribute to all four fields but only aldosterone; James Tait did not work on DNA for his PhD; the Taits did not work on saturation analysis with Ekins. The book does acknowledge my help and encouragement.

\section{John Coghlan}

Menzies Foundation, 210 Clarendon Street, East Melbourne, 3002 Australia E-mail:coghlan@vicnet.net.au

In his review of Sylvia and James Tait's Quartet of Unlikely Discoveries Sir Richard Bayliss says, 'In conjunction with Roger Ekins, the Taits developed immunoassay techniques for the measurement of thyroid hormones ... .'. In their book they made no claim to have done so. In the early to mid 1950s the Taits were primarily engaged in work on 
hormones of the adrenal cortex, which culminated in their discovery of 'electrocortin' (aldosterone). I, on the other hand, working on radioisotope techniques for diagnosis and therapy, had reached the conclusion that radioisotopic tests of thyroid function could not be reliably interpreted without knowledge of the blood levels of thyroid hormone. Thus, albeit for differing reasons, both the Taits and I had an interest in measurement of hormones in blood. The technique they used for steroid hormones in many of their pioneering studies was the double-isotope labelled reagent method - too arduous and time-consuming for use in routine diagnosis. In 1954 I hit upon the concept I termed 'saturation analysis' (later generally known as 'ligand' or 'binding' assay), but 5 years were to pass before I had the opportunity to develop and publish a T4 binding assay employing radioiodinated thyroxine. The Taits moved to the Worcester Foundation in 1957. I do recall a conversation with James Tait (in the showers after a game of squash) in which I outlined the saturation analysis principle. He responded very encouragingly, but this was the entire extent of the Taits' participation in the development of binding assay techniques for the thyroid hormones.

\section{Roger Ekins}

Division of Molecular Endocrinology,

University College London Medical School,

London W1T 3AA, UK

E-mail:r.ekins.@ucl.ac.uk

\section{Sir Walter Langdon-Brown and hormonology at the RSM}

Professor Hadden (July $2005 J R S M^{1}$ ), citing Hunting's The History of the Royal Society of Medicine, ${ }^{2}$ claims that the RSM's Section of Endocrinology, constituted in 1945, was the brainchild of Dr Raymond Greene. This is at variance with what the endocrinologist Dr S L Simpson added to the obituary of Sir Walter Langdon-Brown in the BMJ ${ }^{3}$ in 1946 in writing that he was the moving spirit in the initiation of the Section, with his inaugural address 'The birth of modern endocrinology' ${ }^{4}$ characteristically invigorating and creative.

Sir Walter, born in 1870, consulting physician to St Bartholomew's Hospital and Regius Professor of Physic, University of Cambridge, 1932-1935, was president of three sections of the RSM - those of Urology, Therapeutics and Pharmacology, and History of Medicine-before becoming first president of the Section of Endocrinology. His book The Endocrines in General Medicine ${ }^{5}$ (1927) later gave rise to the claim that he could be regarded as the founder of modern clinical endocrinology in this country. In his Horsley Memorial Lecture 6 on 'The integration of the endocrine system' in 1935, he remembered as an undergraduate at Cambridge in 1892 the excitement of hearing Victor Horsley give a paper on the function of the thyroid gland. It was in this lecture that Langdon-Brown famously named the pituitary gland as the leader of the endocrine orchestra, something he modified in his last (inaugural) lecture at the RSM by recognizing 'that the hypothalamus holds the still more important rank of conductor'.

Milo Keynes

3 Brunswick Walk, Cambridge CB5 8DH, UK

\section{REFERENCES}

1 Hadden DR. 100 years of hormonology: a view from No. 1 Wimpole Street. J R Soc Med 2005;98:325-6

2 Hunting P. The History of the Royal Society of Medicine. London: RSM Press, 2002:382-3

3 Simpson SL. Addition to Obituary of Sir Walter Langdon-Brown. BMJ 1946;ii:556-7

4 Langdon-Brown $\mathrm{W}$. The birth of modern endocrinology. Proc R Soc Med 1946;39:507-10

5 Langdon Brown W. The Endocrines in General Medicine. London: Constable, 1927

6 Langdon-Brown W. The Integration of the Endocrine System. Cambridge: Cambridge University Press, 1935 